\title{
Acute and Sub acute Toxicity Studies of Pterocarpus Erinaceus in Rats
}

\author{
Ajayi Victoria Folashade, Uguru Mary
}

\begin{abstract}
AIMS- To evaluate the acute and subacute toxicity of methanolic leaf extract of pterocarpus erinaceus in Albino Rats.

MATERIALS AND METHODS --- Acute oral toxicity study of methanolic leaf extract were carried out by administration of $10,100,1000,1600,2900$, and $5000 \mathrm{mg} / \mathrm{kg}$ bodyweight to rats.Sub-acute toxicity study was conducted according to the OECD guideline were the first group of rats served as the control group while the other three groups were given Pterocarpus erinaceus extract at doses of $250,500,1000 \mathrm{mg} / \mathrm{kg}$ for a period of 28 days after which biochemical and histological studies were carried out.

RESULTS---In acute toxicity study no mortality or any behavioural changes and extract was found to be safe up to $5000 \mathrm{mg} / \mathrm{kg}$. In the subchronic study no mortality or morbidity, no significant changes in weight of the rats. A slight significant decrease in cholesterol, high density lipoprotein, no significant change in triglyceride, low density lipoprotein, haematological parameters and indices when compared to control group. Increase in ALT, ALP at lower doses while at higher dose there was a decrease. No significant difference in serum protein, urea and creatinine. The histological studies of the organs (liver ,kidney and heart showed no distortion in architectural structure at lower doses but there was a slight distortion at higher doses.
\end{abstract}

CONCLUSION----- The present study indicate that this extract is safe for human consumption and its has ability to lower the lipid profile which may be good for both hypertensive and diabetic patients.

Index Terms - Pterocarpus erinaceus, phytochemical analysis , acute toxicity, sub-acute toxicity, Biochemical parameters.

\section{INTRODUCTION}

P. erinaceus Poir (Fabaceae) is a small to medium sizedeciduous legume tree that is $12-15 \mathrm{~m}$ tall and $1.2 \mathrm{~min}$ diameter. The bark of the trunk is dark grey and rough with scales that curl up at the ends. The leaves are compound and imparipinnate. It is distributed throughoutthe West and Central African savanna and dry forest. It is popularly known as 'African rosewood'. In northern Nigeria, it is called "Madobiya" or "Shajini", while in thesouth; it is called "Apepe" or "Osun dudu". A decoction of the stem bark is used as astringent for severe diarrhea and dysentery and as an ingredient in abortifacient prescriptions. It is also used as a dressing on ring worm of the scalp and chronic ulcers

Ajayi Victoria Folashade, ( B.Pharm, M.Sc Pharmacology), Department of Pharmacology, Faculty of Pharmaceutical Sciences, University of Jos, Nigeria

Uguru Mary, (B.Sc,M.Sc,Ph.D) Department of Pharmacology, Faculty of Pharmaceutical Sciences, University of Jos, Nigeria
(Dalziel, 1948). In someparts of Kano in Northern Nigeria, its decoction is used orally to arrest bleeding (Khamis Sangarib, verbal communication).

The heartwood is a source of a red dye, which is used for drying body, hair and cloth. The bark is used for tanning. The reddish bark exudates is known as kinotannic acid and is used in traditional medicine internally to treat diarrhea, dysentery, fever, gonorrhea, intestinal worms, and externally to treat eye complaints, ulcers and sores. Kinotannic acid has strong astringent property. Decoctions or infusions of the bark or roots is used for treating bronchial infections, toothache, menstruation complaints, anaemia, post-partum haemorrhage, ringworms, leprosy, wounds, tumors, antiemetic, purgative and tonic. Leaf decoctions are applied to treat syphilis

(Duvall, 2008). The leaves is used as febrifuge, the bark is used for tooth and mouth troubles. The grated root is mixed with tobacco and smoked in a pipe as a cough remedy. The aqueous extract of Pterocarpus erinaceus stem bark has anti-inflammatory, analgesic and antioxidant activities (Anne, 2012). The anti-malaria (Karou et al., 2003), anti-helmintic (Maidou et al., 2005) and anti-gonadotropic (Benie et al., 2003) activities of the plant has been investigated. The plant has both in-vitro and in-vivo anti-mycotic activity (Etuk et al., 2008). The plant is very popular among the Hausa speaking people of North-western Nigeria because of its medicinal properties. The stem bark decoction is taken orally for gastrointestinal upset (ICRAF, 1998).

The bark extracts showed in-vitro antibacterial and antifungal activities. It blocks the ovulation and oestrus cycle of female rats through antigonadotropic activity. The effectively of the bark as a wound-healing agent was due to the presence of phenolic compounds that have an effect on the complementary system (part of the immune system). The bark has significant antioxidant activity. One of the reasons for the increasing interest in herbal medicines is the belief that because these medicines are natural and have been traditionally used, they are safe and harmless. Nevertheless, their natural origin is not a guarantee of safety, as many reports concerning the risks associated with the use of herbal products have noted (Chan, 1997; Ernst, 1998; Vaes and Chyka, 2000; Whiting et al., 2002). Hence, scientific information regarding the safety of this plant for use as an alternative medicine is very important before it is further developed into a new medicinal herbal therapy. Therefore, the objectives of the present study were to determine the acute toxicity, and subchronic toxicity effects of P.erinaceus extractin vivo. 


\section{METHODS}

\section{Phytochemiccal screening}

The Phytochemical screening was carried out according to protocols described in Trans and Evans (1985)

\section{Acute Toxicity Testing}

The Lorke method was used. This method is divided into two phases; Nine rats were divided into 3 groups of 3 animals each. Each group of animal was administered different doses (i.e. 10,100 , and $1000 \mathrm{mg} / \mathrm{kg}$ respectively) of the test substance. The animals were placed under observation for 24 hours to monitor their behavior as well as mortality if any.This phase involves the use of 3 animals, which were distributed into 3 groups of one animal each. The animals were administered higher doses (1600, 2900, and 5000 $\mathrm{mg} / \mathrm{kg}$ ) of the test substance. It was then observed for 24 hours for behaviour as well as mortality (Lorke, 1983).

\section{SUB CHRONIC TOXICITY STUDIES ON NORMAL RATS}

The method was performed according to the Organization of Economic Co-operation Development (OECD) test Guideline (2001).Wistar Rats were divided into 4 groups (1-lV) of 6 rats each (3males and 3 females).Control (group1) received 0.1 $\mathrm{ml} / \mathrm{kg}$ distilled water while group ( $11-\mathrm{lV}$ ) received extract at $250 \mathrm{mg} / \mathrm{kg}, 500 \mathrm{mg} / \mathrm{kg}, 1000 \mathrm{mg} / \mathrm{kg}$. All groups were given oral route once a day for a period of 28 days and animals were observed for signs of abnormalities. The body weight of the animals was recorded at the end of each week. The animals were anaesthetized with chloroform and blood was collected by cardiac puncture using capillary tube haematological and biochemical studies were carried out respectively.

\section{Haematological and Biochemical Studies}

\section{Haematological and lipid profile analysis}

Hematological analysis was performed using an automatic hematological analyser. Parameters include Red Blood Cell (RBC), White Blood Cell Count (WBC), Hemoglobin (HGB), Hematocrit (HCT), Mean Corpuscular Volume (MCV), Mean Corpuscular Hemoglobin Concentration (MCHC), Red Cell Distribution Width (RDW), and Mean Platelet Volume (MPV). Lipid profile parameters studied, include; Total Cholesterol, Triglycerides, High-Density Lipoprotein (HDL) and Low-density Lipoprotein (LDL).

\section{Biochemical Analysis}

Biochemical analysis was performed on serum obtained after centrifugation of total blood (without anticoagulant) at 2500 rpm for $15 \mathrm{~min}$. Standardized diagnostic kits (Labkit ${ }^{\circledR)}$ were used for spectrophotometric determination of the following biochemical parameters: alanine aminotransferase (ALT), aspartate aminotransferase (AST), alkaline phosphatase(ALP), total proteins, creatinine and urea.

\section{Liver Markers Enzymes}

Aspartate amino transferase (AST) was evaluated using the method of Reitman and Frankel (1957) as described by Randox laboratories, United Kingdom using Randox kits; Alanine aminotransferase (ALT) was measured by monitoring the concentration of pyruvate hydrazone formed with 2,4-dinitrophenyl hydrazine using the method of
(Reitman and Frankel,1957) as described in Randox kits; alkaline phosphatase (ALP) was assayed based on the methods of ( Kind and King,1972); total protein in serum was assayed using direct Biuret Method (Gornall et al.,1948) .

\section{Estimation of serum urea}

This was done following the method of (Bauer et al., 1982). Urea in serum was hydrolyzed to ammonia in the presence of urease. The ammonia was then measured photometrically by Berthelot's reaction.

\section{Estimation of serum creatinine}

The method of (Cock and Gault, 1976) was employed for the estimation of serum creatinine in which at alkaline $\mathrm{pH}$ values; creatinine reacts with picric acid to produce a colored compound creatinine alkaline picrate which is photometrically read at $546 \mathrm{~nm}$

\section{Histological Studies}

The organs were isolated from the sacrificed animals and grossly examined for any pathological changes and then fixed in $10 \%$ Normal saline for 7 days. The organs were dehydrated in ascending grade of alcohol $(70 \%, 80 \%, 90 \%, 95 \%$ and absolute alcohol) for 2 hours and then clear in xylene for 2 hours after which it was infiltrated in paraffin wax for 72hours and thereafter embedded in blocks of paraffin wax.

Section of the organs were cut at $5 \mu \mathrm{m}$ using microtome. The slides were dried on hot plate prior to staining, it was then dewaxed in xylene for 5 minutes. The organs were then transferred to descending grade of alcohol (Absolute alcohol, $95 \%, 90 \%, 80 \%, 70 \%$ alcohol) for 5 minutes and then wash in water. The organs were then stained in hematoxylene for 7 minutes and washed in water.

The stained organs were differentiated in acid alcohol for 20 seconds and washed in water. The section was blown in scott tap water and washed in water, after which it was counter stained in Eosin for 12 minutes and washed in water. The stained organs were once again transferred to ascending grade of alcohol $(70 \%, 80 \%, 90 \%, 95 \%$, and absolute alcohol) for 5 minutes and then cleared in xylene also for 5 minutes.

Finally, it was mounted with DPS and cover slip and allowed to dry before viewing under the microscope (Ganter and Jolles, 1970; Lucia et al., 2008).

\section{RESULTS}

\section{Phytochemical Screening}

The phytochemical screening revealed the presence of flavonoids, saponins, alkaloids, tannins, steroids, cardiac glycosides while the anthraquinones were absent.

\section{Acute Toxicity}

In the acute toxicity study, Methanolic leaf extract treated animals did not show any change in their behavioural pattern within the period of the study, when compared to the vehicle treated group. Thus, it was concluded that methanolic leaf extract was safe at $5000 \mathrm{mg} / \mathrm{kg}$.

\section{Effects on Body Weight of Rats}

The methanolic leaf extract of Pterocarpus erinaceus administered to the rats for 28 days did not cause any significant change in body weight when compared to the control (Table 1). 
Table 1: Effects of the Methanolic Leaf Extract of $P$. erinaceus on the Body Weight of Rats

\begin{tabular}{llllll}
\hline \multirow{2}{*}{ Treatment } & \multicolumn{2}{l}{ Mean body weight of rats $(\mathrm{g})$} & & \\
\cline { 2 - 6 } & DAY 1 & DAY 7 & DAY 14 & DAY 21 & DAY 28 \\
\hline Control & $131.32 \pm 7.36$ & $131.68 \pm 7.37$ & $132.88 \pm 7.36$ & $134.48 \pm 7.49$ & $135.53 \pm 7.41$ \\
Extract $250 \mathrm{mg} / \mathrm{kg}$ & $120.22 \pm 7.13$ & $125.12 \pm 7.48$ & $125.12 \pm 7.06$ & $126.03 \pm 7.05$ & $126.53 \pm 7.05$ \\
Extract $500 \mathrm{mg} / \mathrm{kg}$ & $132.80 \pm 15.11$ & $134.87 \pm 15.17$ & $134.87 \pm 15.19$ & $135.87 \pm 15.30$ & $136.37 \pm 15.26$ \\
Extract $1000 \mathrm{mg} / \mathrm{kg}$ & $130.80 \pm 8.41$ & $134.30 \pm 8.46$ & $134.30 \pm 8.42$ & $135.28 \pm 8.75$ & $136.17 \pm 8.77$ \\
\hline
\end{tabular}

Values are expressed as mean $\pm \operatorname{SEM}(n=6)$

There was no significant difference $(\mathrm{P}<0.05)$ in the mean weight of the animal across the study group when compared to the control.

The result in (Table 2) revealed a significant decrease in cholesterol and high density lipoprotein in the study group as compared to the control group while triglyceride and low density lipoprotein no significant difference.

Table 2: Effect of Methanolic Leaf Extract of Pterocarpus erinaceus on Lipids Profile

\begin{tabular}{lllll} 
Treatment & \multicolumn{2}{l}{ Mean Lipids Profile $(\mathbf{m m m o} / \mathbf{l})$} & & \\
\cline { 2 - 5 } & TRIG & CHOL & HDL & LDL \\
\hline Control & $0.74 \pm 0.07$ & $1.52 \pm 0.16$ & $0.96 \pm 0.06$ & $0.49 \pm 0.09$ \\
Extract $250 \mathrm{mg} / \mathrm{kg}$ & $0.76 \pm 0.10$ & $0.80 \pm 0.16^{*}$ & $0.45 \pm 0.09^{*}$ & $0.38 \pm 0.07$ \\
Extract $500 \mathrm{mg} / \mathrm{kg}$ & $0.69 \pm 0.04$ & $1.54 \pm 0.14^{*}$ & $0.92 \pm 0.04^{*}$ & $0.47 \pm 0.05$ \\
Extract $1000 \mathrm{mg} / \mathrm{kg}$ & $0.72 \pm 0.05$ & $1.22 \pm 0.11^{*}$ & $0.73 \pm 0.09^{*}$ & $0.48 \pm 0.07$ \\
\hline
\end{tabular}

Values are expressed as mean \pm SEM $n=6$,

*Value significant at $\mathrm{P}<0.05$

Keys:TRIG-Triglyceride,CHOL-Cholesterol,HDL-High Density Lipoprotein,LDL-Low Density Lipoprotein

The methanolic leaf extract of $P$. erinaceus showed no significant difference in the haematological parameters of the study group relative to the control group. There were no significant differences in haematological indices of the treated group as compared to control in (Table 3 and 4).

Table 3: Effect of Methanolic Leaf Extract of Pterocarpus erinaceus on Haematological Parameters

\begin{tabular}{|c|c|c|c|c|c|c|}
\hline \multirow{2}{*}{$\begin{array}{l}\text { Treatment } \\
\text { group }\end{array}$} & \multicolumn{6}{|c|}{ Mean Haematological Parameters } \\
\hline & $\begin{array}{l}\text { WBC }\left(10^{9}\right. \\
/ L)\end{array}$ & ${ }_{L} \operatorname{RBC}\left(10^{12} /\right.$ & $\begin{array}{l}\text { HGB(HGB } \\
\text { g/L) }\end{array}$ & HCT (\%) & PLT(10 $9 / \mathrm{L})$ & $\underset{(\%)}{\text { RDW }}$ \\
\hline \multirow[t]{2}{*}{ Control } & $12.14 \pm 1.6$ & $8.08 \pm 0.19$ & $132.2 \pm 3.91$ & $44.55 \pm 1.2$ & $496.60 \pm 47.12$ & $16.82 \pm 0.3$ \\
\hline & 8 & & \multicolumn{2}{|c|}{5} & \multicolumn{2}{|r|}{9} \\
\hline Extract $250 \mathrm{mg} / \mathrm{k}$ & $13.67 \pm 3.3$ & $8.34 \pm 0.22$ & $134.0 \pm 2.39$ & $45.17 \pm 0.7$ & $602.60 \pm 21.11$ & $16.84 \pm 0.4$ \\
\hline g & 5 & & \multicolumn{2}{|c|}{7} & \multicolumn{2}{|r|}{6} \\
\hline Extract $500 \mathrm{mg} / \mathrm{k}$ & $11.94 \pm 2.7$ & $7.60 \pm 0.35$ & $119.8 \pm 6.62$ & $41.40 \pm 2.1$ & $723.60 \pm 84.48$ & $17.74 \pm 0.3$ \\
\hline g & 0 & & \multicolumn{2}{|c|}{7} & \multicolumn{2}{|r|}{6} \\
\hline Extract $1000 \mathrm{mg} /$ & $12.16 \pm 2.1$ & $8.04 \pm 0.33$ & $132.6 \pm 6.19$ & $45.73 \pm 2.0$ & $588.80 \pm 50.23$ & $17.02 \pm 0.2$ \\
\hline $\mathrm{kg}$ & 1 & & \multicolumn{2}{|c|}{1} & \multicolumn{2}{|r|}{9} \\
\hline
\end{tabular}

Values are expressed as mean \pm SEM,n $=6$

There was no significant difference $(\mathrm{p}<0.05)$ in the meam haematological parameters of the animals across the study group, as compared to the control group.

Keys:WBC-white blood cell, RBC-Red blood cell,HGB-Haemoglobin,HCT-Haematocrit,PLT-Platelet, RDW-Red blood cell distribution width:

Table 4: Subchronic Effect of Methanolic Leaf Extract of Pterocarpus erinaceus on Haematological Indices.
Treatment group
Means Haematological Indices

\begin{tabular}{lcccccc} 
& PDW (\%) & MPV(fL) & MCH(pg) & MCHC(g/L) & MCV(fL) & PCT (\%) \\
\hline Control & $31.96 \pm 0.30$ & $6.90 \pm 0.08$ & $63.38 \pm 0.16$ & $287.80 \pm 1.02$ & $57.00 \pm 0.55$ & $0.34 \pm 0.03$ \\
Extract250mg/kg & $33.08 \pm 0.61$ & $7.18 \pm 0.21$ & $15.98 \pm 0.22$ & $296.60 \pm 5.26$ & $54.40 \pm 1.29$ & $0.43 \pm 0.01$
\end{tabular}


Acute and Sub acute Toxicity Studies of Pterocarpus Erinaceus in Rats

$\begin{array}{lllllll}\text { Extract500mg/kg } & 32.76 \pm 0.34 & 6.98 \pm 0.21 & 16.28 \pm 0.61 & 289.80 \pm 3.48 & 54.60 \pm 1.63 & 0.50 \pm 0.06 \\ \text { Extract1000mg/kg } & 33.24 \pm 0.27 & 7.12 \pm 0.24 & 16.08 \pm 0.13 & 289.80 \pm 2.71 & 57.00 \pm 1.05 & 0.42 \pm 0.04\end{array}$

Values are expressed as mean \pm SEM, $n=6$

There was No significant difference $(\mathrm{p}<0.05)$ in the mean haematological indices of the animal across the study group, as compared to the control.

KEYSPDW $=$ Platelet Distribution Width ,MPV= Mean Platelet Volume, MCH= Mean Corpuscular haemoglobin, $\mathrm{MCHC}=$ Mean Corpuscular Hemoglobin Concentration, PCT= Mean Platelet Volume

(Table 5) below showed the methanolic leaf extract of Pterocarpus erinaceus which shows a significant $(\mathrm{P}<0.05)$ increase in Alanine aminotransferase when compared with control. There is also an increase in Alkaline phosphatase (ALP) at dose of $250 \mathrm{mg} / \mathrm{kg}$ and $500 \mathrm{mg} / \mathrm{kg}$ and a decrease at dose of $1000 \mathrm{mg} / \mathrm{kg}$. There was no significant difference for aspartate aminotransferase when compared to control.

Table 5: Effect of Methanolic leaf Extract of Pterocarpus erinaceus on liver Enzymes

\begin{tabular}{llll}
\hline TREATMENT & \multicolumn{2}{c}{ Means Liver Enzymes } & \\
\cline { 2 - 4 } & AST(U/L) & ALT(U/L) & ALP(U/L) \\
\hline Control & $39.17 \pm 1.30$ & $6.56 \pm 2.02$ & $76.76 \pm 13.91$ \\
& & & \\
Extract $250 \mathrm{mg} / \mathrm{kg}$ & $41.12 \pm 3.88$ & $13.76 \pm 0.46^{*}$ & $140.03 \pm 24.98^{*}$ \\
Extract $500 \mathrm{mg} / \mathrm{kg}$ & $39.00 \pm 3.33$ & $13.67 \pm 1.83^{*}$ & $126.78 \pm 12.15^{*}$ \\
& & & \\
Extract $1000 \mathrm{mg} / \mathrm{kg}$ & $35.64 \pm 2.23$ & $13.81 \pm 2.28^{*}$ & $72.42 \pm 6.98^{*}$ \\
\hline
\end{tabular}

Values are expressed as mean \pm SEM, $n=6$

*Indicates significant difference $(\mathrm{P}<0.05)$ in the ALT,ALP of the animal across the study group compared to control.

Keys:AST- Aspartate transaminase,ALT-Alanine transaminase ,ALP-Alkaline phosphotase The methanolic leaf extract of Pterocarpus erinaceus showed no significant difference $(\mathrm{P}<0.05)$ for serum protein, creatinine and urea when compared to control in Table 6.

Table 6: Effect of Methanolic leaf Extract of Pterocarpus erinaceus on SerumProtein, Urea and Creatinine

\begin{tabular}{|c|c|c|c|}
\hline \multirow[t]{2}{*}{ Treatment Group } & \multicolumn{3}{|c|}{ Mean Urea and Creatinine } \\
\hline & Total protein $(\mathrm{g} / \mathrm{l})$ & Urea(mmol/L) & Creatinine(Umol/l) \\
\hline Control & $85.12 \pm 2.17$ & $4.65 \pm 0.34$ & $1.48 \pm 0.06$ \\
\hline Extract $250 \mathrm{mg} / \mathrm{kg}$ & $72.33 \pm 4.48$ & $4.96 \pm 0.29$ & $1.23 \pm 0.04$ \\
\hline Extract $500 \mathrm{mg} / \mathrm{kg}$ & $84.39 \pm 3.79$ & $5.16 \pm 0.32$ & $1.37 \pm 0.07$ \\
\hline Extract $1000 \mathrm{mg} / \mathrm{kg}$ & $77.59 \pm 4.62$ & $3.94 \pm 0.34$ & $1.39 \pm 0.08$ \\
\hline
\end{tabular}

Values are expressed as mean $\pm S E M, n=6$

There was no significant difference $(\mathrm{P}<0.05)$ in the Serum Urea, Creatinine, Total Protein of the animal across the study group compared to control.

The relative weights of some of the essential organs like liver and kidneys of the treated rats were slightly significant greater than that of the control and there was a slight increase in weight of the kidney and liver as compared to the control (Tables 7 and 8).

Table 7: Effects of the Methanolic Leaf Extract of $P$. erinaceus on the Weight of the Rat's Liver

\begin{tabular}{lc}
\hline Treatment $(\mathbf{m g} / \mathbf{k g})$ & Liver weight $(\mathbf{g})$ \\
\hline Control & $6.04 \pm 0.01$ \\
Extract 250 & $7.51 \pm 0.05 *$
\end{tabular}


Values are expressed as mean \pm SEM

Number of animals, $\mathrm{n}=6$

*Significant difference in the mean weight of the liver as compared to the control $(\mathrm{P}<0.05)$

Table 8: Effects of the Methanolic Leaf Extract of $P$. erinaceus on the Weight of the Rat's Kidneys

Treatment(mg/kg) Right kidney weight $(g) \quad$ Left kidney weight(g)

$\begin{array}{lll}\text { Control } & 0.66 \pm 0.00 & 0.65 \pm 0.00\end{array}$

$\begin{array}{lll}\text { Extract } 250 & 0.54 \pm 0.00 * & 0.53 \pm 0.00 *\end{array}$

$\begin{array}{lll}\text { Extract } 500 & 0.57 \pm 0.01 * & 0.55 \pm 0.01 *\end{array}$

$\begin{array}{lll}\text { Extract } 1000 & 0.35 \pm 0.01 * & 0.33 \pm 0.01 *\end{array}$

Values are expressed as mean $\pm S E M, n=6$

*Significant difference of the mean weights of both kidneys as compared to the control $(\mathrm{P}<0.05)$

There was no significant difference between to heart weight of the treated group when compare with the control in (Table 9).

Table 9 Effects of the Methanolic Leaf Extract of $P$. erinaceus on the Weight of the Rat Heart

\begin{tabular}{ll}
\hline Treatment $(\mathbf{m g} / \mathbf{k g})$ & Heart weight $(\mathbf{g})$ \\
\hline Control & $0.73 \pm 0.01$ \\
Extract 250 & $0.75 \pm 0.20$ \\
Extract 500 & $0.73 \pm 0.30$ \\
Extract 1000 & $0.75 \pm 0.20$ \\
\hline
\end{tabular}

Values are expressed as mean $\pm S E M, n=6$

There was No significant difference $(\mathrm{P}<0.05)$ in the mean weight of the animal heart across the study group compared to control.

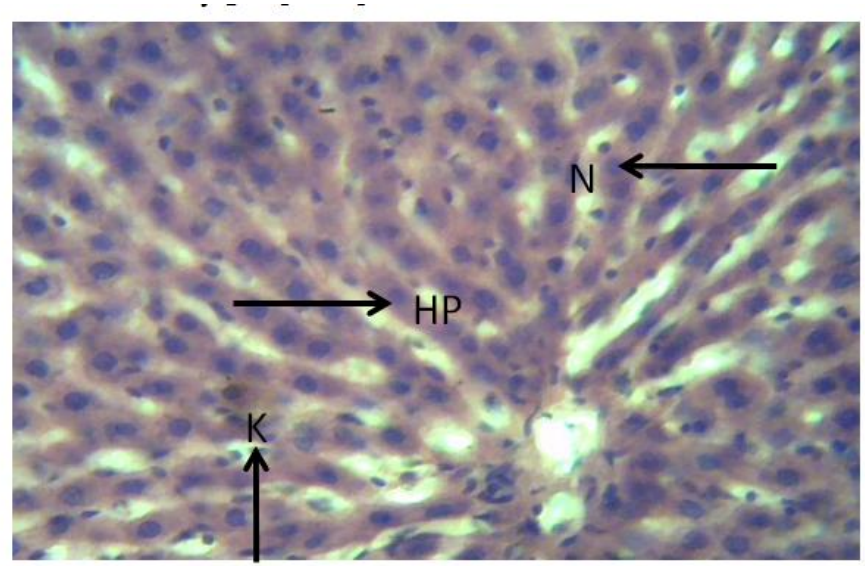

Plate 1: Control Liver Using Distilled Water On The Test Magnification $x 400$

1. Right arrow shows a normal radial arrangement of hepatocytes

2. Up arrow shows presence of kupffer cell within the sinusoid

3. Left arrow shows a normal nuclei within the hepatocytes 


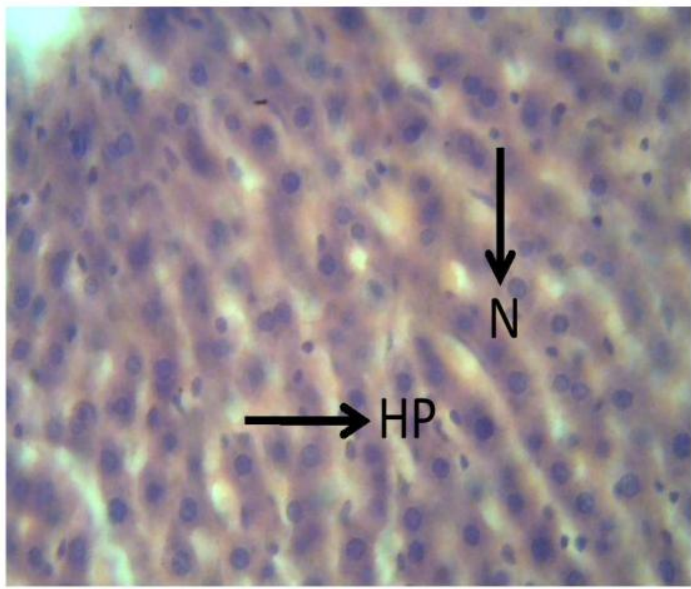

Plate 2: Effect of the Methanolic Leaf Extract $500 \mathrm{mg} / \mathrm{kgof} P$. erinaceus on the Rat Liver

\section{Magnification x 400}

1. Right arrow shows a normal radial arrangement of hepatocytes with presence of kupffer cell within the sinusoid

2. Down arrow shows a normal nuclei within the hepatocytes

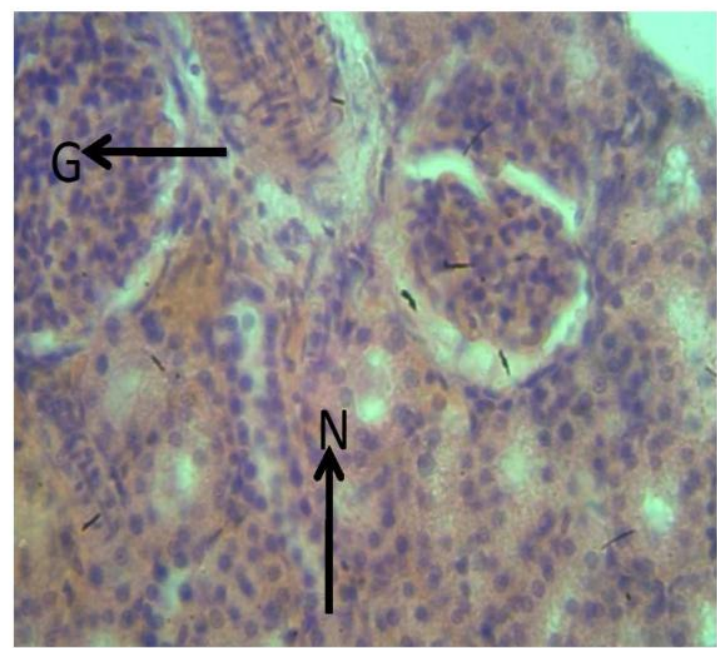

Plate 4: Control Kidney Using Distilled

\section{Water On The Test}

Magnification x 400

1. Left arrow shows a normal glomeruli

2. Up arrow shows a normal nuclei within the collecting duct

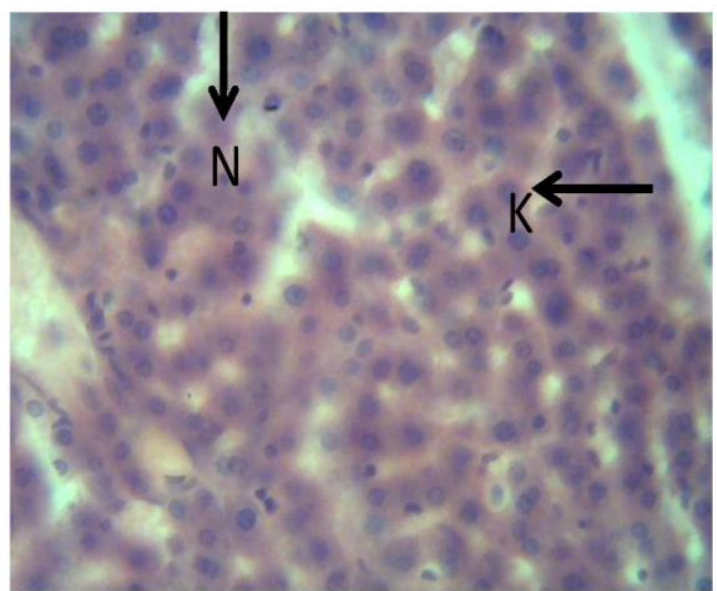

Plate 3: Effect of the Methanolic Leaf Extract $1000 \mathrm{mg} / \mathrm{kgof} P$. erinaceus on the Rat Liver

Magnification x 400

1. Down arrow shows presence of few kupffer cell within the sinusoid

2. Left arrow shows an enlarge nuclei with massive distortion of the radial arrangement of hepatocytes

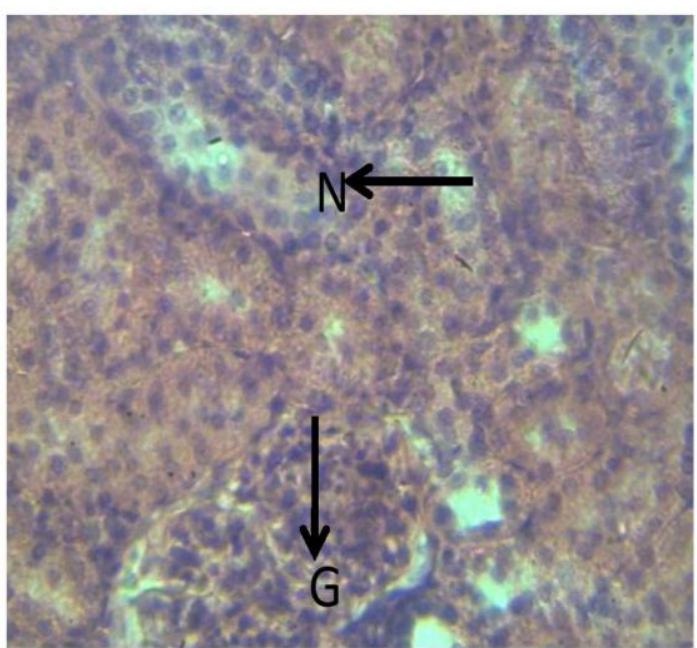

Plate 5: Effect of the Methanolic Leaf Extract $250 \mathrm{mg} / \mathrm{kgof} P$. erinaceus on the Rat Kidney

Magnification x 400

12. Down arrow shows a normal glumeruli

2. Left arrow shows a Normal Nuclei within the collecting duct 


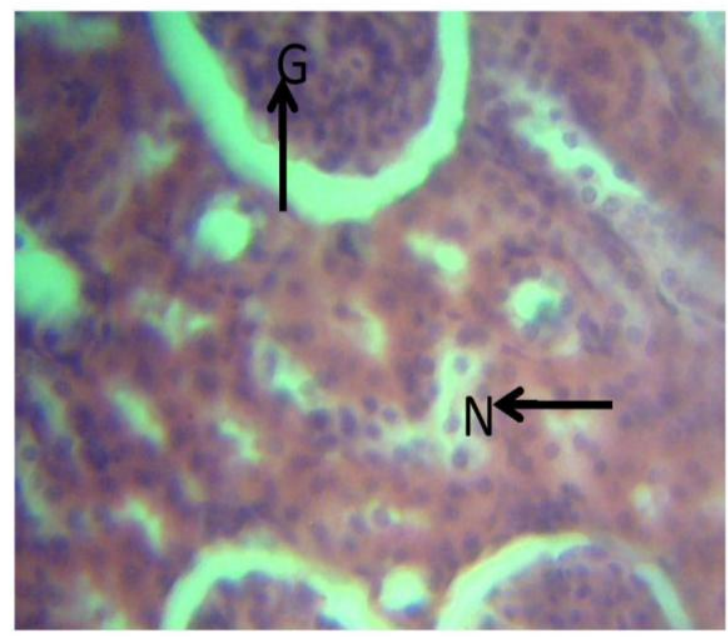

Plate 6: Effect of the Methanolic Leaf Extract $500 \mathrm{mg} / \mathrm{kgof} P$. erinaceus on the Rat Kidney

Magnification x 400

1. Up Arrow shows a Normal Glomeruli

2. Right arrow shows a Normal Nuclei within the collecting duct

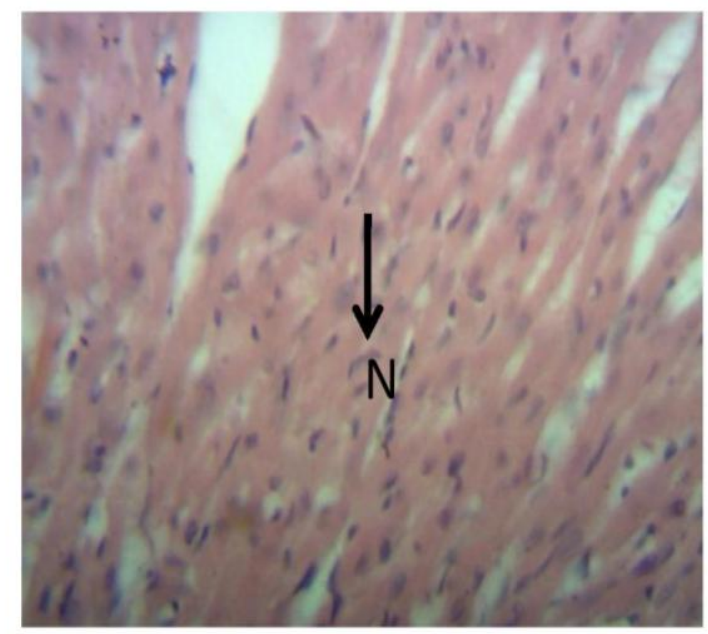

Plate 8:Control Heart Using Distilled Water On The Test

Magnification x 400

1. Down arrow shows normal nuclei within the muscle cell

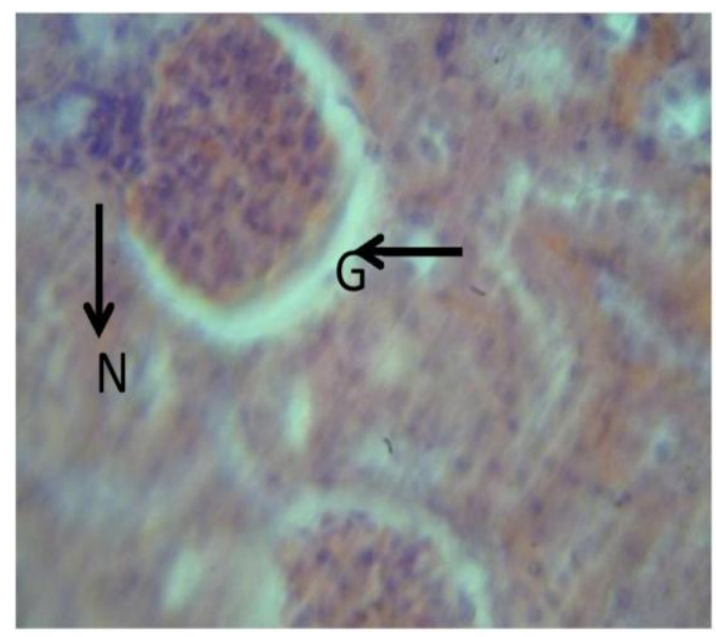

Plate 7: Effect of the Methanolic Leaf Extract $1000 \mathrm{mg} / \mathrm{kgof} P$. erinaceus on the Rat Kidney

Magnification x 400

1. Left arrow shows Infraction of glomeruli

2. Down arrow shows distortion of the collecting duct with partial loss of nuclei within the collecting duct

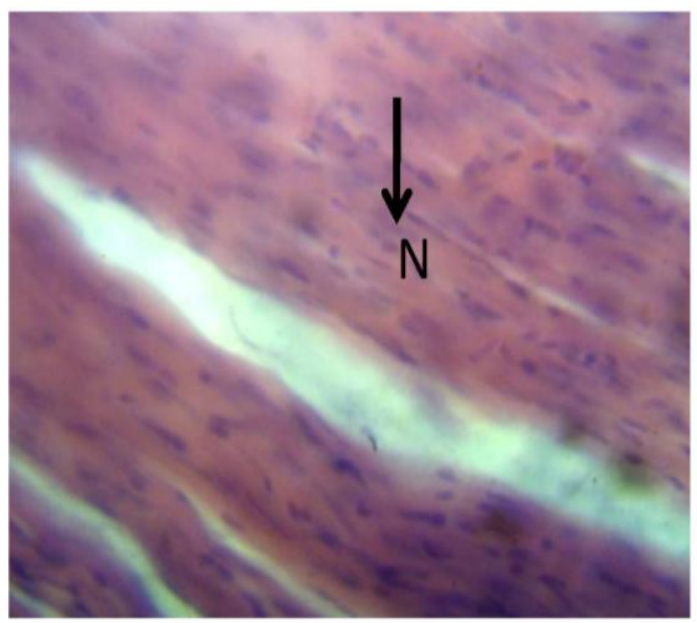

Plate 9: Effect of the Methanolic Leaf Extract $250 \mathrm{mg} / \mathrm{kgof} P$. erinaceus on the Rat Heart

\section{Magnification x 400}

13 1. Down arrow shows a Normal Nuclei within the muscle cell 


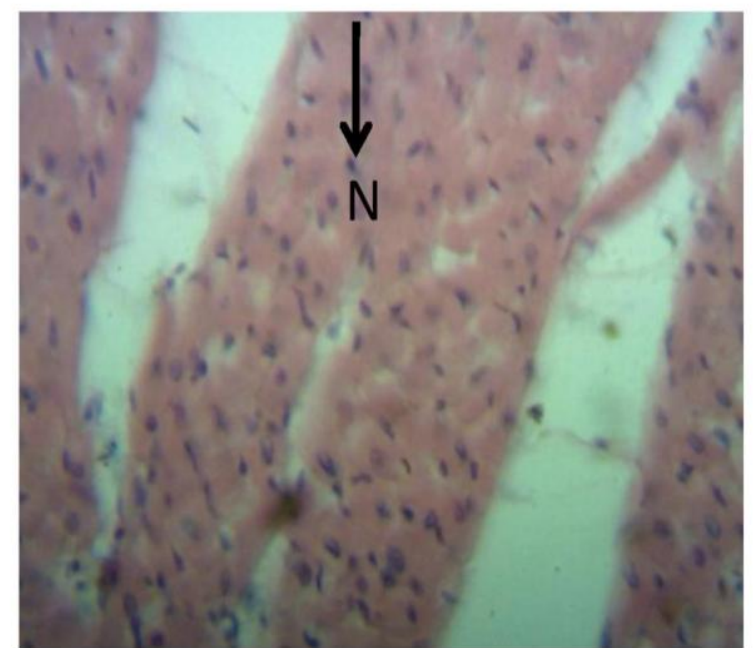

Plate 10: Effect of the Methanolic Leaf Extract $500 \mathrm{mg} / \mathrm{kgof} P$. erinaceus on the Rat Heart

$$
\text { Magnification x } 400
$$

\section{Down arrow shows a Normal Nuclei within} the muscle cell

\section{DISCUSSION}

Oral administration of the crude extract appeared to be well tolerated by the rat. According to the WHO, medicinal plants have been found to be relatively safe (Amenya et al., 2014). In the acute toxicity study, no mortality or behavioural, respiratory patterns or somatomotor activities of toxicity were observed following the oral administration of Methanolic extract at $1600 \mathrm{mg} / \mathrm{kg}, 2900 \mathrm{mg} / \mathrm{kg}$ and $5000 \mathrm{mg} / \mathrm{kg}$. Therefore, the LD50 of Methanolic extract is much higher than $5000 \mathrm{mg} / \mathrm{kg}$ in rats, which also corroborates the previous findings on P.erinaceus extracts (Salawu et al., 2008). These kinds of extract are considered as practically non-toxic and they are widely used as food and herbs (Awounfack et al., 2016)

The sub-acute treatment indicated that Pterocarpus erinaceus extract in doses of 250,500 and $1000 \mathrm{mg} / \mathrm{kg}$ per day during 28 consecutive days did not produce any deaths or clinical signs of toxicity as shown (Table 1). A decrease in body weight would be an indication of adverse effect as stated by (Olson et al., 2000), there were no significant changes in the body weight, animal behaviour. This may be an indication that the extract does not affect the feed utilization ratio of the animals reported by (Saidu et al., 2007).

In general, increase or decrease in the body weights of animals can be used as an indicator of adverse effect of drugs and chemicals (Teo et al., 2002). However, weight of animals

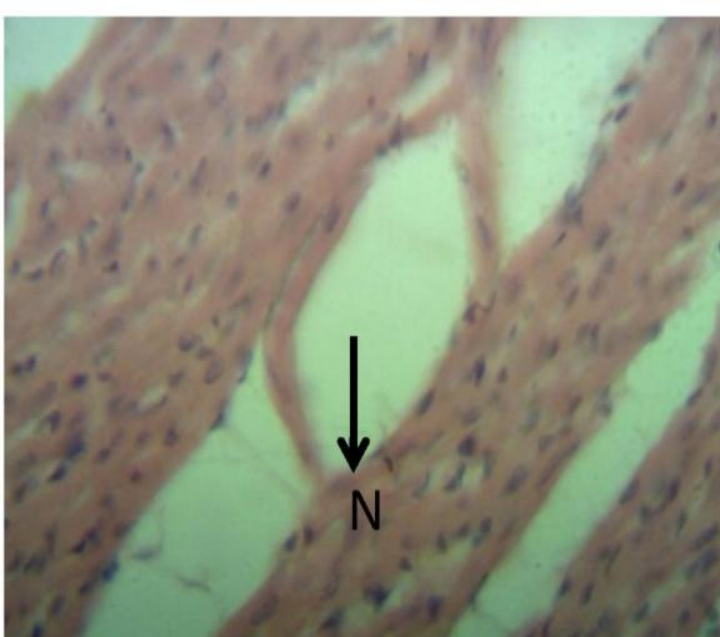

\section{Plate 11: Effect of the Methanolic Leaf Extract $1000 \mathrm{mg} / \mathrm{kgof} P$. erinaceus on the Rat Heart}

Magnification x 400

\section{Down arrow shows a Normal Nuclei within}

the muscle cell

are more closely related to body fat accumulation rather than to the toxic effects of drugs or chemicals (Rhiouani et al., 2008) suggested that reductions in the body weights of animals in toxicity studies may be associated with normal physiological adaptation responses to the plant extracts or compound which lead to low appetite and hence, lower caloric intake by the animal. High doses of the plant extracts or compound might also induce stress in the animals, thereby reducing their food intake, which may lead to reductions in their body weight (Harri's et al., 1998). Pterocarpus extract did not appear to affect the body weights of the rats entering dose throughout the treatment periods.

Apart from the mortality rate, cage side functional observations including the valuation of changes in skin, fur and eyes as well as respiratory effects, autonomic effects, and newly system effects are very important in toxicity studies.( Eaton and Klaassen , 1996) suggested that animals given high doses of plant extracts or chemicals might show slight changes in behaviour as a consequence of the metabolism of the plant extracts or chemicals. However, the signs are quickly reversible (Eaton and Klaassen, 1996). The rats in the present toxicity studies showed neither signs of behavioural changes nor abnormalities in the parameters mentioned.

In the lipid profile study there was a general decease in the cholesterol ,triglyceride,HDL, LDL, as when compared to the control but more of decrease was revealed at $250 \mathrm{mg} / \mathrm{kg}$ (Table 2) The lipid lowering effect of the extract, may be attributed to the hypolipidemic agents in the herbal drug (Ogbonnia et al., 2011). Lipids and lipoprotein abnormalities 
are preceding factors for cardiovascular diseases and prevalence of this in general populations has increased considerably in the last few decades. Hyperlipidemia contributes significantly to the prevalence and severally of anthrosclerosis and coronary heart diseases (Gosain and Jain, 2009). Increasing level of lipids lead to cardiovascular diseases and stroke. Flavonoid containing plants have influence on arachidonic acid, metabolism, thus could have anti-inflammatory, anti-allergic, anti-thrombotic or vaso-protective effects, (Evans, 2002). The presence of alkaloids has further confirmed its medicinal use as an antihyper - lipidemic agent. It might be hypothesized that alkaloid compound A could inhibit lipogeneous which in turn helps treating type 4 and type 5 hyperlipidemia. This explains the lipid lowering effect of the alkaloid compound A of Anethum gravealens which revealed that this compound could inhibit carbohydrate absorption and metabolism (Gosain et al., 2010).The cholesterol lowering effect of the plant extract may possibly be associated with a decrease in intestinal absorption of cholesterol, resulting in an increase in fecal excretion of neutral lipids (Purobit and Vyas, 2006).

No significant alteration of the heamatological parameters and heamatological indices can be attributed to this plant extract (Table 3and 4). Heamatological and biochemical profiles of blood can provide important information about the internal environment of the organism (Velisek et al., 2005). These findings are supported by the result of (Garg et al., 2004) who reported that treatment of broilers chicks with monocrotophis did not cause any significant change in erythrocyte and PCV values. Evaluation of heamatological parameters is important in toxicity assessment as changes in heamatological indices have a higher predictor value for human toxicity (Adebayo et al., 2005). Sub-chronic administration of methanolic leaf extract Pterocarpus erinaceus daily for 28 days did not cause any significant change in heamatological profile as compared to the control.This is similar to the finding of (Olorunisola et al., 2012). However, the values obtained are within the normal range (Olson et al., 2000). The results showed no deleterious effects on blood cells counts and haemoglobin content thereby suggesting that Pterocarpus erinaceus had no toxic effect on blood system.

The importance of $\mathrm{MCH}, \mathrm{MVC}$, and $\mathrm{MCHCH}$ in anaemia diagnosis in most animals has been highlighted (Coles, 1986). From this result, extract did not significantly alter the circulatory RBC indices.. The non-significant effect of the extracts on RBC, HGB, ROW, MCV, MCH, Platelets and MCHC means that the extract does not affect erythropoesis, morphology or osmotic fragility of the red blood cells (Guyton and Hall, 2000). The hematopoiesis and leucopoiesis were also not affected even through the hematopoietic system is one of the most sensitive target for toxic compounds (Harper, 1973). An important index of physiological and pathological status in man and animals (Adeneye et al., 2006).Maxwell et al., (2014) also reported that no toxic effect on hematopoietic system as there was no significant change in haematological parameters of Gauania longipetala which is in agreement with this study.

No significant change in AST (Asperate transaminase) but there was slight alteration in Alkaline Phosphates (ALP) and (ALT) Alanine transaminase when compared to control in (Table 14) all the values remained within normal limits at the termination of the study, this indicate no effect on the hepatocyte function (Olorunisola et al., 2012).Assessment of liver and kidney function is very important in toxicity evaluation of drugs and plant extracts as they are both necessary for the survival of an organism. AST and ALT activities are common measured to monitor liver damage. A mild or higher activity of AST indicate liver injury or myocardial infarction (Feldman and Zinkl, 2000; Crook, 2006) but in this study the Pterocarpus erinaceus extract did not induce any damage to the liver as revealed by the results that no significant change in AST.

Although, there was slight increase in ALT and ALP which are classical enzymes reliable indices of liver toxicity (Hayes, 1989) since in this study the enzymes shows no appreciable increased in the treated animals it implied that the extract has no hepato-toxic effect. The rise in the AST as normally accompanied by elevation in the level of ALT (Dash et al., 2007). The levels of ALT and AST can be used to monitor possible adverse effect of drugs on the liver and kidney functions (Vijayalakshoni et al., 2000). Also ALT was a reliable indicator of liver necrosis in small animals (Choudhari and Deshomukh, 2007). AST is an enzyme of the biliary treat indicative of injury to the hepatobiliary, cholecystitis and hepatic necrosis (Dash et al., 2007). In this study no marked increase of AST and ALT was observed after 28 days of extracts administration which is clear that extract does not exert any liver and kidney damage. ALP is an enzyme that transports metabolites across cell membrane. liver and bone diseases are the most common of the pathological elevation of ALP levels although ALP may originate from the other tissue, and as the placenta, kidney or intestines or leukocyte (Fishman, 1999) but in this study slight elevation of the ALP indicate no effect.

Effect of urea, creatinine, total protein and Albumin. Reduction in total protein and albumin are indications of diminished synthetic function of the liver or might be due to impaired hepatocellular function. Low serum albumin content may suggest infection or continuous loss of albumin (Tietz et al., 1994, Yakubu et al., 2003). Thus, the insignificant change in serum concentration of total protein, albumin in the treatment and control group as represented in (Table 5) further suggests that the extract does not impair hepatocellular or secretary function of the liver at any of the doses. Kidney function was evaluated by means of serum urea, creatinine concentrations. Increased blood creatinine is a good indicator of compromised kidney function. The renal function profile, serum creatinine and urea levels was not significantly, altered compared to control (Table 5). These compounds which are non-protein nitrogenous substances are said to be end products of protein metabolism that must be removed continually (Guyton, 1981). The insignificant changes in creatinine and urea levels suggested that the activity of protein metabolism was maintained with the normal range due to relatively non-toxic effect of the extract.

Blood urea and consequently non protein nitrogen level was found raised into terminal stages of chromic nephritis, in some cases acute nephritis and in congental cystic kidney. Likewise, creatinine is the least venable nitrogenous 
constituents of blood. The value is increased in early nephritis and in chronic hemorrhage nephritis with uremia. Similarly, increased blood content of creatinine has been reported in renal injury subsequent to trauma or anuria in traumatic injuries to the muscles and in muscular dystrophy. Treatment with Pterocarpus erinaceus extract does not have any significant alteration in blood creatinine level which suggested that no damages was done to the kidney.

Assessment of the effect of the plant extracts on body weight and organs of experimental animals is an important test in toxicity evaluation. The alteration in overall body weight or organ body weight ratio is an indication of impairment in the normal functioning of the organ (Amresh et al., 2008). In this study there was a slight significant increase $(\mathrm{P}<0.05)$ in weight of liver as compared to control (Table 6). The relative weight of some of the essential organs like liver and kidney as presented increase than that of control, this might be as a result of alkaloids and flavonoids present in high amount (Monika Mahajan et al., 2004 Cemak, 2008). There was no significant difference between the heart weights of the treated groups into that of the control, suggesting that administration of Pterocarpus erinaceus extract had a cardio protective effect. Difference in the sex of experimental animals despite the use of the same spaces of animals could also account for the discrepancy in the weight of the organs. (Adeneye et al., 2004). The slight increase may be due to the variation of the size and weight of animal's organs (Lillie et al., 1996; Carol, 1995). However, similar findings were reported (Ogbonnia et al., 2010).

\section{Histological Studies}

From the results obtained from the effects of the leaf of Pterocarpus erinaceus on the liver showed that at the dose $500 \mathrm{mg} / \mathrm{kg}$, there was no distortion of the hepatocytes presence of kupffer cell are within the sinusoid and normal nuclei are also within the hepatocyte when compared with the control (Plate 1,2). The rats given $1000 \mathrm{mg} / \mathrm{kg}$ of the Pterocarpus erinaceus showed presence of few kupffer cell within the sinusord and enlarge nuclei with massive distortion of the radial of the hepatocytes (Plate 3). The liver of the rats given at lower dose of the extract showed normal arrangement of liver cell presence of kupffer cells while the liver of the rat given $1000 \mathrm{mg} / \mathrm{kg}$ of the extract showed a distorted arrangement of the liver (cells hepatocytes) absence of the kupffer also was seen which affect the cells. The distortion at higher dose may be as result of toxic substance present in the extract as the higher the dose, the more available toxic substance that will be present in the extract similar findings was observed by (Hinnri et al., 2005).

The histopathogical evidence revealed in the pathological lesions showed no destruction, no lost of architecture and damages to the kidney at lower dose $250 \mathrm{mg} / \mathrm{kg}$ and $500 \mathrm{mg} / \mathrm{kg}$ while there was distortion of the collecting duct with partial loss of nuclei within the collecting duct for $1000 \mathrm{mg} / \mathrm{kg}$ of extract when compared to the control(Plate 4, 5, 6, 7) similar finding was observed by (Magilli et al., 2014). The toxic irritant substance brought to the kidney by circulating blood cause degenerative changes in the kidney tissues according to (Varley, 1997). Also Akubue, 2006 reported that accumulation of toxic waste products in the kidney can result into reduction in the excretory, function of the kidney.

The change in architectural structure of the liver and kidney at higher dose may be due to toxins content in the extract (Evans, 1996). It can be seen that the extract at the various doses in (Plate 8, 9, 10,11) did not cause an changes in architecture structure of the heart when compared with the control result obtained is similar to finding of (Chia et al., 2012).

\section{Conclusion}

The present studies demonstrated that P.erinaceus extract lacks the toxic effects that could compromise the medicinal use of this plant as an herbal medicine.No mortality was found after 48 hours administration, this indicates that extract has a high $\mathrm{LD}_{50}$ value and suggests a wide margin of safety for human use. In the repeated dose oral toxicity studies (28days),there were no toxic effects observed with regard to the behaviour, body weight, haematological and biochemical parameter and histological studies.The present findings show that P.erinaceus extract is not likely to produce any toxicological effects suggesting safety for medicinal use.

\section{REFERENCES}

[1] Adebayo, J., Adesokan, A., Olatunji, L., Buoro, D \& Soladoye, A. (2005) Effect of ethanolic extract of Baugainvillea spectabilis leaves on hematological and serum lipid variables in rats. Journal of Biochemistry Nigerian Society for Experimental Biology, 17,45-50.

[2] Adeneye, A.A., Ajagbonna, O.P., Adeleke, T.I., Bello, S.O. (2006) Preliminary toxicity and phytochemical studies of the stem bark aqueous extract of Musanga cecropioides in rats. Journal of Ethnopharmacology, 105, 374-379.

[3] Akubue P. I. (2006) Text book of Pharmacology, $1^{\text {st }}$ Edition, Africana First Publishers limited Onitsha, Nigeria. Pp 14.

[4] Amenya HZ, Gathumbi PK, Mbaria JM, Thaiyah AG, Thoithi GN Sub-acute toxicity of the chloroformic extract of Rapanea melanophloeos (L) Mez in rats. J Ethnopharmacol. 2014; 154:593-599.

[5]Amresh, G. R., Singh, P. N., Rao, V.C. (2008). Toxicological screening of traditional medicine Laghupatha (Cissampelos pareira) in experimental animals. Journal of Ethnopharmacol, 116, 454-460.

[6]Andrew ,W. (1966). Comparative hematology. New York: Grune Stratton, pp.144-146.

[7]Anne, (2012). Antioxidant, anti-inflammatory and analgesic activities of aqueous extract from stem bark of Pterocarpus erinaceus poir.Journal of Medicinal plantresearch, 5(10), 2047-2053

[8] Awounfack CF, Ateba SB, Zingue S, Mouchili OR, Njamen D. Safety evaluation (Acute and Sub-acute studies) of the aqueous extract of the leaves of Myrianthus arboreus P. Beauv. (Cecropiaceae) in Wistar rats. J Ethnopharmacol. 2016; 194:169-178.

[9]Bauer, J.H.,Brooks,C.S.,\&Burch,R.N.,(1982).Renal function studies in man with advanced renal insufficiency. Am.J.Kidney Dis.11,30-35.

[10] Benie, T., Duval, T., \& Thieulant, M. L. (2003). Effect of some traditional plant extracts on rat oestrous cycle compared with clomid. Phytotherapia Research, 17,748-755.

[11] Cemak, R. (2008). Effect of Dietary Flavonoids on Pathways Involved in Drug Metabolism. Expert opinion in Drug Metabolism and Toxicology, 4 (1), 845-848.

[12] Chia, J. C., Thing, F. T., Shorong, S. L., Yuan, S. C., \& Min, L. (2012) Acute and 28-Day Subchronic Oral Toxicity of an Ethanol Extract of Zingiber zerumbet (L.) Smith in Rodents Evidence-Based Complementary and Alternative Medicine Volume 2012, Article ID 608284,11 pages

[13] Choudhari, C. V., \& Deshmukh, P. B. (2007). Acute and subchronic toxicity study of Semecarpus anacardium on hemoglobin percent and RBC count of male albino rat. Herbal Medicine Toxicol, 1, 43-45. 
[14] Cockcroft,D.W.\&Gault,M.H.,1976.Prediction of creatinine from serum clearance from serum creatinine.Nephron16,31-41.

[15] Coles, E. H. (1986). Veterinary clinical pathology. W. B Saunders, Philadelphia, USA, 10-42.

[16] Crook, M. A. (2006). Clinical Chemistry and Metabolic Medicine. $7^{\text {th }}$ Edition. London: Hodder Arnold, pp.426.

[17] Dash, D. K., Yeligar, V. C., Nayak, S. S., Ghosh, T.,\& Rajalingam, D. (2007). Evaluation of hepatoprotective and antioxidant activity of Ichnocarpus frutescent (Linn.) on paracetamol-induced hepatotoxicity in rats. Trop. J. Pharm. Res., 6, 755-765.

[18] Dalziel JM (1948). The Useful Plants of West Tropical Africa. The Crown Agents for the colonies. London, p. 611.

[19] Duvall OS ,(2016).Pterocarpus erinaceus poir.(internet)Retrieved fromProta.http://www.prota4u.org/search .asp.>accessed 15th ,march 2015 .

[20] Eaton, D. L., \& Klaassen, C. D. (1996). Principles of toxicology. In: C.D. Klaassen, (Ed.), Casarett and Doull's Toxicology: The Basic Science of Poisons, 5th ed. McGrawHill, pp. 13.

[21] Etuk, E. U., Suberu, H. A., Ameh, I. G., Abubakar, K. (2008). Anti-mycotic effect of the aqueous leaf extract of Pterocarpus erinaceus in rats. Journal of pharmacology and toxicology, 3,318-323.

[22] Evans, W. E (2002). Trease and Evans Pharmacognosy. $15^{\text {th }}$ ed. London:W.B Saunders and co. Ltd.

[23] Evan,W.E (1996) Trease and Evans Pharmacognosy A text book of Pharmacognosy, $14^{\text {th }}$ Edition. Baillirere Tindal.

[24] Feldman, B. V., \& Zinkl, J. G. (2000). Schalm's Veterinary Hematology, 5th ed. Philadelphia, Lea Febiger pp.1210-1218.

[25] Ganter, P., \& Jolles, G. (1970). In tissus conjonctifs in histochimie normales et pathologique, Gauthier-Villars Paris. pp. 1045-1126.

[26] Garg, A. K.., Pal, G. J., \& Jadhao, S. B. (2004). "Haemato-biochemical and immuno- pathophysiological effects of chronic toxicity with synthetic pyrethroid, organophosphate and chlorinated pesticides in broiler chicks," International Immuno pharmacology, 4,(13), 1709-1722.

[27] Gornall, A. G., Bardawill, C. S., \& David, M. M. (1948). Determination of serum proteins by means of the biuret reactions.J.Biol.Chem, 177,551.

[28] Gosain, S. R., Ircchiaya, C. P., Sharma, S., Tharejad A., Kalra A., Deep, \& Bhardwaj Y. (2010). Hypolipidemic effect of ethanolic extract from the leaves of Hibiscus sabdariffa (Linn) in hyperlipidemic rats.

[29] Guyton, A. C. (1981). Textbook of medical pathology, $6^{\text {th }}$ ed. USA W. B. Saunders Company, Philadelphia, 463-474.

[30] Guyton, A. C., \& Hall, J. E. (2000). Textbook of Medical Physiology (10th Edition) Harcourt International Edition, W.B Saunder Company Philadelphia. Pp.279-281.

[31] Harper, H. A. (1973). Review of Physiological Chemistry, 14th ed. California :Lange Medical Publications.

[32] Hayes, M. L. (1989). Guidelines for acute oral toxicity testing. In: Principles and methods of toxicology. 2nded. 143-152.

[33] Harris, R. B., Zhou, J., Youngblood, B. D., Rybkin, I. I., Smagin, G. N.,\& Ryan, D. H. (1998). Effect of repeated stress on body weight and body composition of rats fed low-and high-fat diets. Am. J. Physiol. Regul. Integr. Comp. Physiol, 275,R1928-R1938.

[34] Himri, I., Bellahcen, S., Souna, F., Belmekki, F., Aziz, M., Bnouham, M. \& Saalaoui, E. (2005). A 90 day oral toxicity study of tartrazine, a synthetic food dye, in wistar rats. Int. J. Pharm.Pharm. Sci., 3, 160-169.

[35] ICRAF, (1998). Tree database. International Centre for Research in Agro Forestry, R7588/ZFD133, pp: 21.

[36] Karou, D., Dicko, M. H., Sanon, S., Simpore, J.,\& Traore, S. A. (2003). Anti-malarial activity of Sida acuta Burm (Malvaceae) and Pterocarpus erinaceus Poir (Fabaceae). Journal of EthnoPharmacol, 89,291-294

[37] Locke, D. (1983). A New Approach to Plant Acute Toxicity Testing. Toxicology,54, 275-287.

[38] Magili, S.T., Maina, H.M., Barminas, J.T., \& Toma,I.(2014) Toxicity study of aqueous leaf extracts ofSarcocephalus latifolius (Rubiaceae) in rats. Merit Research Journal of Environmental Science and Toxicology, 2(6), 120-128.

[39] Maidou, K. W., Kamanzi, A. K., Traore, D.,\& Bruno, B. (2005) Antihelminthic activity of medicinal plants used in Northern Cote d'Ivoire against intestinal helminthiasis. J Pharm Biol, 43, 72.

[40] Maxwell, O. E., Emmanuel, U. E., Shaibu Oricha Bello1 \& Sanusi Wara Hassan(2014). Antidiabetic potential of liquid-liquid partition fractions of ethanolic seed extract of Corchorus olitorious. Journal of Pharmacognosy and Phytotherapy,6(1), 4-9.

[41] Monika, M. (2004). Properties, Application \& pharmacological effects of alkaloids; pp 1-36

[42] OECD (2001).The OECD guideline for testing of chemical. The organization of Economic co-operation development, Paris pp.1-14.

[43] Ogbonnia, S O., Mbaka, G. O., Anyika, E. N., Ladiju1, O., Igbokwe, H. N., Emordi, J. E.,\& Nwakakwa, N. (2010). Evaluation of Anti-diabetics and Cardiovascular Effects of Parinari curatellifolia Seed Extract and Anthoclista vogelli Root Extract Individually and Combined on Postprandial and Alloxan-Induced Diabetic Albino Rats Br. J. Med. Med. Res, 1(3),146-162.

[44] Olorunnisola, O. S., Bradley, G. \&Afolayan, A. J. (2012). Acute and sub-chronic toxicity studies of methanolic extract of Tulbaghia violacea rhizomes in Wistar rats. African Journal of Biotechnology, 11(83), 14934-14940.

[45] Olson, H., Betton, G., Robinson, D., Thomas, K., Monro. A., Kolaja, G., Lilly, P.... (2000). Concordance of toxicology of pharmaceuticals in humans and animals. Regul. Toxicol. Pharmacol, 32,56-67.

[46] Purohit,A.\&Vyas, K. B. (2006). Antitherosclerotic effect of Capparis deciduas fruit in cholesterol -fed rabbits. Pharmacological Biology,44,172-177.

[47] Reitman, S. \& Frankel, A.S. (1957). A colorimetric method for the determination of serum glutamic oxaloacetic and glutamic pyruvic transaminase, American J Clin Pathol, 28, 53.

[48] Rhiouani, H. R., Nazari, P., Kamli-Nejad, M., \& Lyoussi, B. (2008) Acute abdsubchronic oral toxicity of an aqueous extract of leaves of Herniariaglabra in rodents. J. Ethnopharm, 118,378-386.

[49] Saidu, Y. L. S., Bilbis, M. L., Isezuo, S. A., Hassan, S. W. \& Abbas, A Y. (2007). "Acute and sub-chronic toxicity studies of crude aqueous extract of Albizzia chevalieri harms (Leguminosae)," Asian Journal of Biochemistry, 2,(4), 224-236.

[50] Salawu, O.A., Aliyu, M., \&Tijani, A.Y. (2008): Haematological studies on the ethanolic stem bark extract of Pterocarpus erinaceus Poir (Fabaceae). African Journal of Biotechnology, 7(9), 1212-1215.

[51] Teo, D., Stirling, S., Thomas, A., Hoberman, A., Kiorpes, \& Khetani, V. (2002). A 90-day oral gavages toxicity study of D-methylphenidate and D,L-methylphenidate in Sprague-Dawley rats, Toxicology, 179, 3), 183-196.

[52] Tietz, N. W., Prude, E. L., \& Sirgard-Anderson, O., (1994). Tietz Textbook of Clinical Chemistry. London, UK: WB Saunders Company.

[53] Trease and Evans (1985). Pharmacognosy; 12th edition by Bailliere Tindal, London. pages 138-240

[54] Vaes,L.P.J.,Chyka,P.A.,(2000).interactionofwarfarinwithgarlic,ginger ,ginkgo,orginseng:natureoftheevidence.AnnalsofPharmacotherapy34, 1478-1482

[55] Varely, H. (1997). Practical Clinical Biochemistry, $6^{\text {th }}$ ed. London Heinemann Medical Books pp. 477-549.

[56] Velisek, J., Svobodova, Z., Piackova, V.,\& Groch, L. (2005). Effects of clove oil anaesthesia on common carp (Cyprinus carpio L.) Veterinarni Medicina, 50(6), 269-275.

[57] Vijayalakshmi, T., Muthulakshmi V. \& Sachdanandam, P. (2000) Toxic studies on biochemical parameters carried out in rats with Serankottai nei, a siddha drug-milk extract of Semecarpus anacardium nut. J. Ethnopharmacol, 69 , 9- Whiting,P.W.,Clouston,A.,Kerlin,P.,(2002).Blackcohoshandotherh erbalremediesassociatedwithacutehepatitis.MedicalJournalofAustrali a177,440-443.

[58] Yakubu, M. T., Bilbis, L. S., Lawal, M., \& Akanji, M. A. (2003) Effect of repeated administration of sildenafil citrate on selected enzyme activities of liver and kidney of male albino rate. Niger. J. Pure Appl. Sci,18,1395-4000. 